\title{
Viking Age tar production and outland exploitation
}

\author{
Andreas Hennius
}

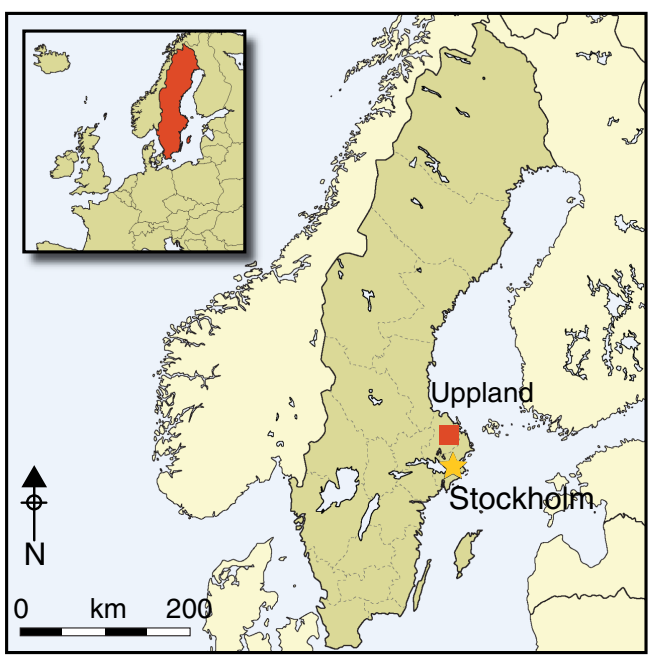

The use of tar and resinous substances dates back far into Scandinavian prehistory. How it was produced, however, was unknown until recent excavations in eastern Sweden revealed funnel-shaped features-now identified as structures for producing tar. A new way of organising tar production appeared in the eighth century $A D$, leading to large-scale manufacture within outland forests. Intensified Viking Age maritime activities probably increased the demand for tar, which also became an important trade commodity. The transition to intensive tar manufacturing implies new ways of organising production, labour, forest management and transportation, which influenced the structure of Scandinavian society and connected forested outlands with the world economy.

Keywords: Scandinavia, Sweden, Viking Age, trade networks, sails, shipping, non-agrarian production, tar, shielings

\section{Early tar production in Sweden: techniques and evolution}

Tar is obtained from wood that is heated in a low-oxygen environment. While tar can be extracted from most types of wood, the most common source in Scandinavia is pine, with birch bark used occasionally for special purposes (Persson 1994). Tar (and its derivative: pitch) has been used for many purposes, including in leatherworking, lubrication, corrosion protection, flavouring and medical treatments. By far the most common use, however, has been in the treatment, protection and sealing of wooden constructions (Persson 1994: 1-2). Various resinous substances were employed far back into Scandinavian prehistory, with the earliest examples of birch resin mixed with beeswax being used as glue or sealants from the Mesolithic onwards (c. 8000-4000 BC) (Heron et al. 1991: 325, 329-30).

* Department of Archaeology and Ancient History, Uppsala University, Box 626, SE-751 26 Uppsala, Sweden (Email: andreas.hennius@arkeologi.uu.se)

(C) Antiquity Publications Ltd, 2018. This is an Open Access article, distributed under the terms of the Creative Commons Attribution licence (http://creativecommons.org/licenses/by/4.0/), which permits unrestricted re-use, distribution and reproduction in any medium, provided the original work is properly cited.

ANTIQUITY, 92365 (2018): 1349-1361

https://doi.org/10.15184/aqy.2018.22 
In the early modern period, tar was one of the most important export products from Sweden (which included Finland and was part of Sweden until 1809). It was produced in huge amounts using tar kilns or tar dales - cone-shaped pits dug into a natural hill slope (Figure 1). Wood was stacked in the upper part, set alight and covered with turf and charcoal to control the availability of oxygen; heat from the combustion caused the tar to condense out of the wood and drip down inside the kiln. An outlet pipe at the base enabled the separation of the various tar fractions during different phases of the production cycle, and their collection in barrels, while the wood was still burning. Finnish historical sources state that such outlet pipes were introduced in the late medieval period, thus improving safety and efficiency over previous methods and making it possible to produce higher-quality tar (Villstrand 1996: 62).

Until recently, little attention had been paid to prehistoric tar-production methods. In the early 2000s, in the Uppland province of eastern-central Sweden, however, archaeological excavations at settlements in the open fields around Uppsala, in advance of new motorway construction, revealed a series of funnel-shaped pit features (Figure 2). Through analogy with similar discoveries from Central Europe, along with wood-anatomy analysis and geochemical analysis using GC-MS, these features can be linked to the production of tar from pine. Their form suggests the use of a method of production similar to historical tar kilns, although these pits lacked the outlet pipe; the tar instead accumulated in a container at the base of the pit. After burning, the upper section had to be demolished so that the tar could be extracted from the underlying space. The surviving parts of these features are approximately one metre in diameter, and the estimated amount of tar produced per firing would rarely have exceeded 15 litres. Thirtyeight radiocarbon dates retrieved from the pit features indicate that they are contemporaneous with the prehistoric settlements in which they are found. Most date from the Roman Iron Age (AD 100-400), with some later examples (Berggren \& Hennius 2004; Hennius et al. 2005; Hjulström et al. 2006; Hennius 2007: 597; Svensson 2007: 615; Svensson-Hennius 2017).

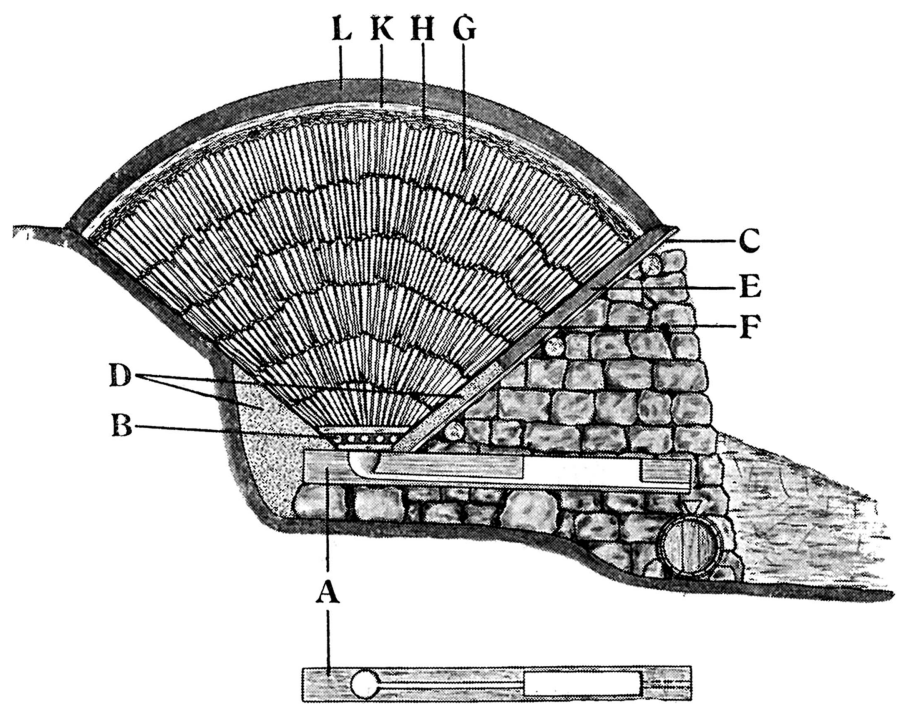

A - Tar outlet pipe

$B$ - Wooden grate

C - Wooden wall

D - Clay filling

E - Soil

F - Birch bark

$G$ - Wood rich in resins

$\mathrm{H}$ - Wooden chips

K - Brushwood

$\mathrm{L}$ - Covering of turf or clay

Figure 1. Schematic section of a tar kiln with a tar outlet pipe in the bottom, used in Scandinavia in historical times (letters I and J are not used) (translation from Bergström 1941: part II, p. 57).

(C) Antiquity Publications Ltd, 2018 


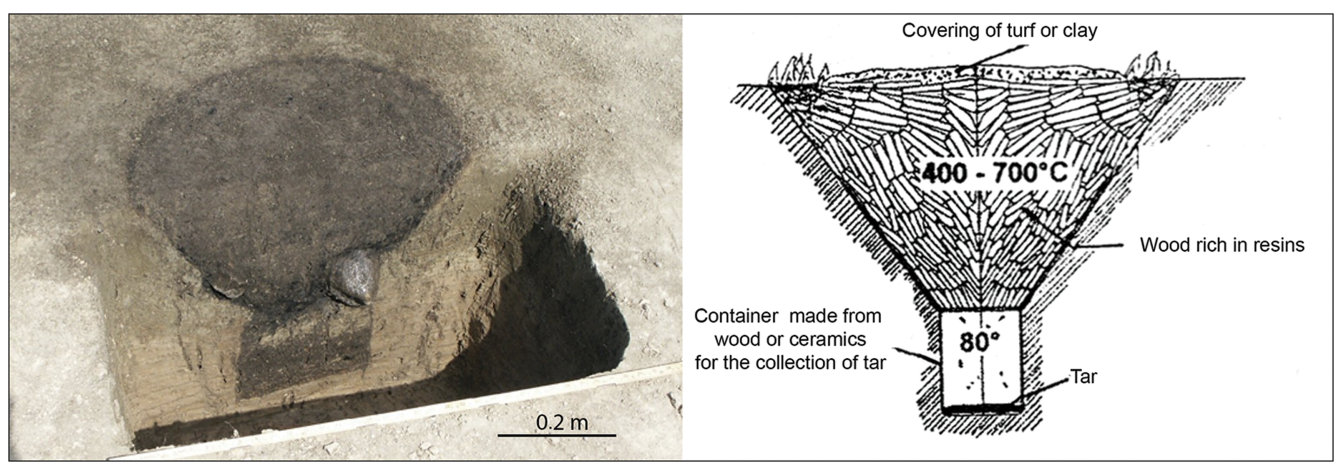

Figure 2. Funnel-shaped feature used for tar production in the Roman Iron Age (photograph courtesy of Upplandsmuseet) and a schematic reconstruction drawing (amended from Kurzweil \& Todtenhaupt 1998).

More tar-production pits were excavated in the forested northern parts of the province, during the same road-construction project. These pits are similar to those found at the settlement sites to the south, with enclosed compartments in the bottom and lacking channels for the continuous drawing of tar. They are, however, up to 10 times larger, and it is estimated that at least 200-300 litres of tar could have been produced per burning episode (Figure 3; Hennius et al. 2005; Hjulström et al. 2006: 292). So far, the seven radiocarbon dates obtained for this second group of pit features suggest that the large-scale production of tar was perhaps already underway in the eighth century AD. Calibrated dates from the three oldest features give a date range of $A D$ 680-900 (at 95.4\% confidence; Figure 4). Several factors must be considered when relying on radiocarbon analysis for dating tar-production features. For large pits that were used repeatedly and that yield an abundance of charcoal, sample context is crucial. To date the features accurately, samples were preferably collected from accumulations of charcoal in the lower part of the feature. The use of old wood is well attested into the nineteenth and twentieth centuries. Microstructural analysis of wood from the tar pits, however, shows the use of 30-40-year-old trunks, with no evidence of insect activity, as would be expected in dead or rotten wood. Both factors indicate the use of fresh wood, which was probably prepared for several years before felling by making cut marks in the bark. This would have promoted an increase in resin production, and thus a greater tar yield upon burning. One of the features was also dated using optically stimulated luminescence (OSL), giving a result consistent with the radiocarbon analysis (Andersson 2005: 26; Hennius et al. 2005: 39; Björck 2008: 107).

The excavation of the large tar-production pits in the forested region identified no nearby associated archaeological features, such as settlements or graves. These large-scale production sites seem, instead, to have been located up to $8 \mathrm{~km}$ from the nearest contemporaneous settlements, identified through burials or structural remains (Hennius et al. 2005: 39, 43; Hennius 2007: 598, 607-609; Hennius 2016). So far, geographic distribution of these tarproduction pits is limited, with a large concentration of at least 125 features to the north of Uppsala, along with a few examples from Norway and Åland (Fredman 2009: 16; SvenssonHennius 2017). There are almost certainly further, as yet undiscovered, tar-production sites in other parts of Scandinavia; many features visible on the ground's surface, and previously 


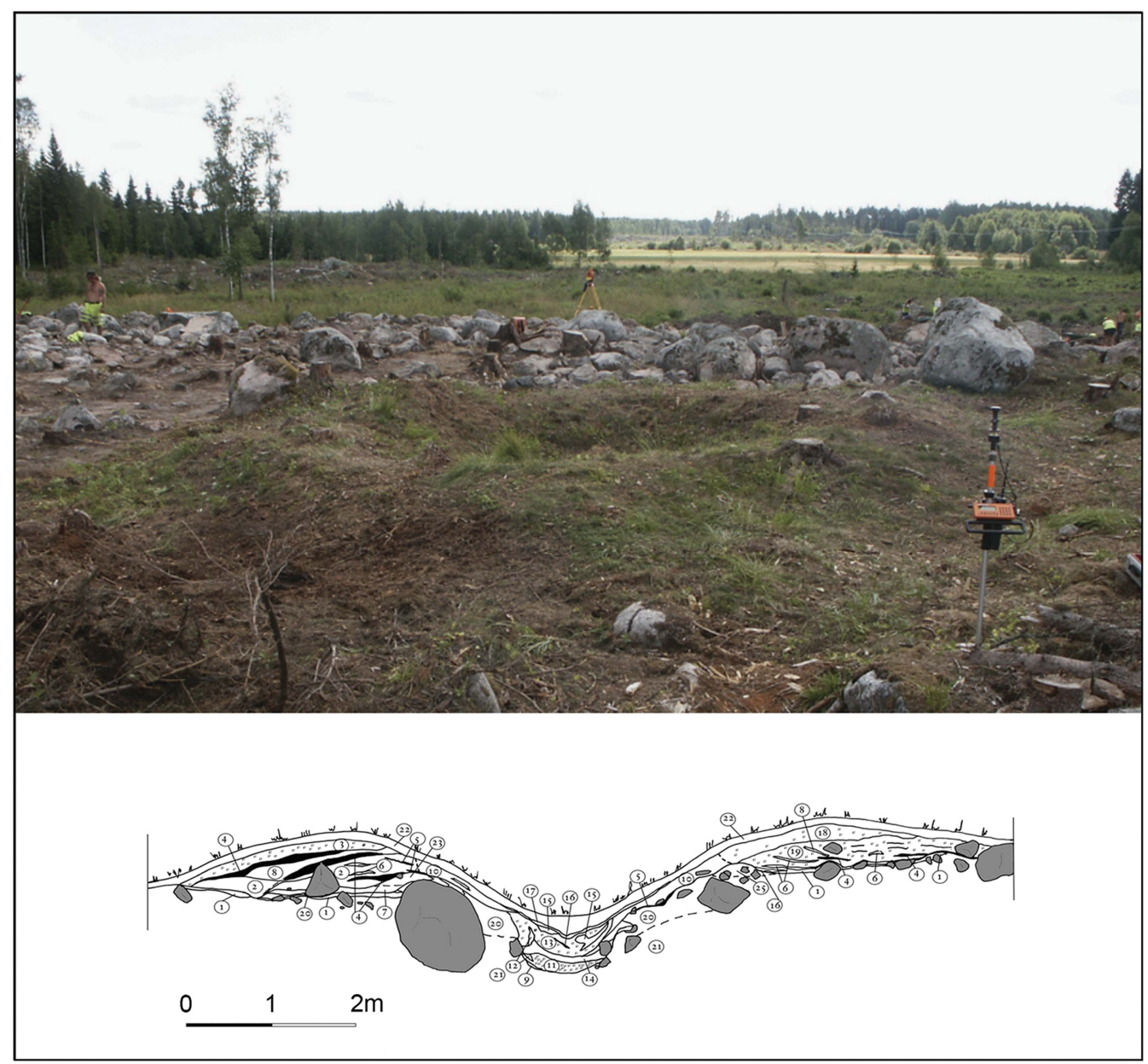

Figure 3. One of the large tar-production pits from a forested area to the north of Uppsala, and the section drawing from the excavation (photograph courtesy of Upplandsmuseet; drawing by Hennius et al. (2005: 21))

interpreted and registered as animal trapping pits or charcoal pits, are similar in form to tarproduction sites and may have been misidentified.

The change in the location and construction of the larger pits seems to signify a shift towards large-scale tar production in the eighth century AD. While it was possible to produce large amounts of tar by repeated firings in the small pits located in the settlements, the eighthcentury change in production location implies an important shift in the mode of production and the organisation of labour associated with the larger pits. These were now strategically located nearer the forested areas, and hence closer to the source of the raw materials. The size of the pits would have also required the planning of wood supply on a larger scale than that needed to fire a small tar pit in a settlement. Building, operating and maintaining the larger pits in the forest would have required considerable and time-consuming work: forest management, cutting trees, chipping and stacking wood, and monitoring the firing. (C) Antiquity Publications Ltd, 2018 


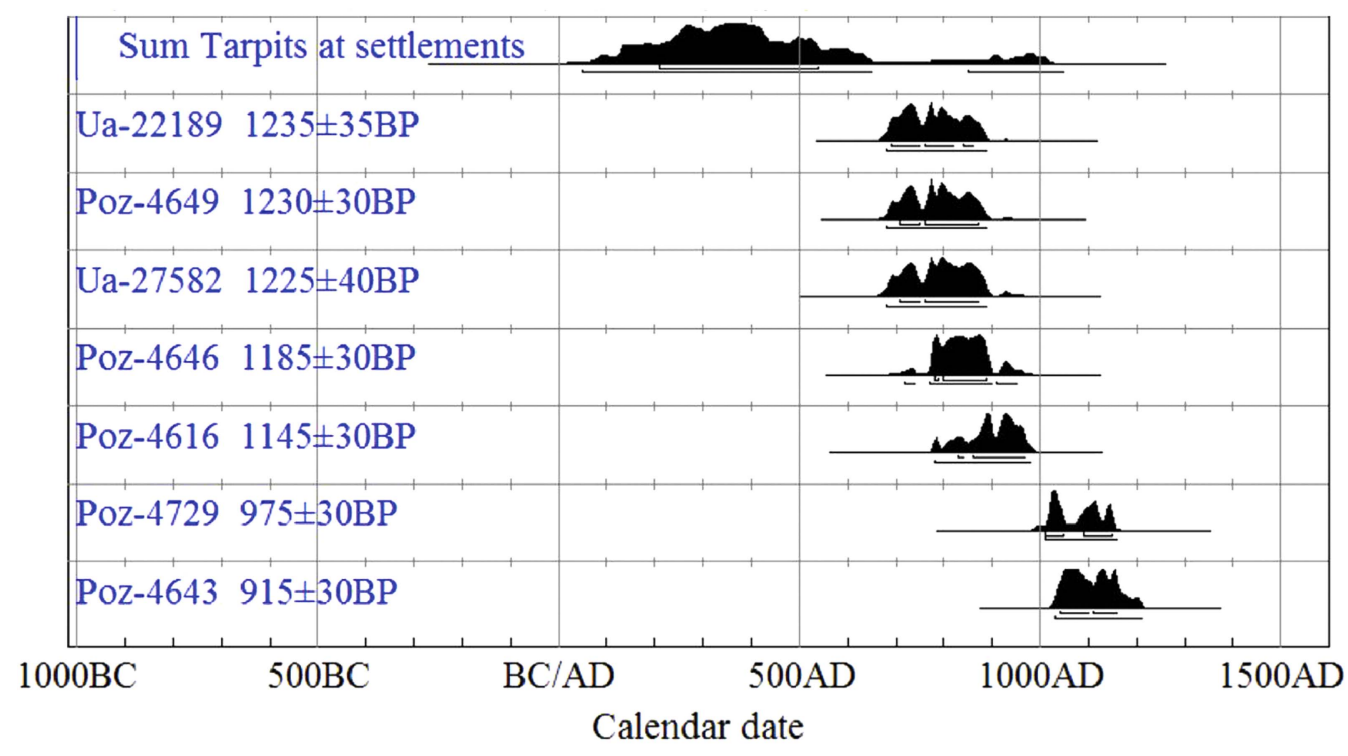

Figure 4. Summarised calibration diagram from 38 tar-production pits excavated at settlement sites (above), and the seven dated tar-production pits from the forests below (Reimer et al. 2004; Bronk Ramsey 2009; unpublished compilation by Svensson-Hennius 2017).

Furthermore, a supply of barrels would have been required for transporting several hundred litres of tar after each production cycle.

Small-scale tar production at settlement sites persisted into the Late Iron Age (c. AD 550 1050, divided into the Vendel Period 550-750 and the Viking Age 750-1050). The tar was probably used during the construction of houses, or for other household activities. Reorganisation to support large-scale outland production external to the settlements therefore suggests an increased demand for tar in other sectors of society. Here, I propose that this increase was synchronous with developments in Viking Age shipbuilding and maritime expansion, and dependent on a reorganisation of land-use, resulting in intensive use of the outlands.

\section{The need for tar in shipping}

The change from small- to large-scale production of tar coincides with an intensified maritime focus, including new shipbuilding techniques, the introduction of the sail and the beginning of far-reaching expeditions across the Baltic (Larsson 2007: 83, 85, 92-95, 114; Bender Jörgensen 2012: 173; Peets et al. 2012: 15; Konsa 2013: 152; Price et al. 2016: 1022; Ravn 2016:31, 100). As in historical times, the need for tar to support Viking Age maritime activities was probably extensive. Based on experiments, Ravn (2016) has estimated the amount of tar required for the construction of a large 'personnel carrier' at approximately 500 litres. This quantity of tar would require approximately $18 \mathrm{~m}^{3}$ of wood, and some 1600 working hours to produce. The Viking fleets mentioned in written sources sometimes included hundreds of ships (Ravn 2016: 31, 70, 100). 
There is archaeological evidence for the use of tar in the Late Iron Age, even if conservation processes complicate analyses. The Vendel Period boat from Sutton Hoo in south-east England, for example, featured not only tarred caulking, but also a bucket of tar mixed with sawdust placed in the central grave chamber (Bruce-Mitford 1975: 341, 456, 486). There are several Scandinavian examples of planks, wooden nails and caulking treated with tar-sometimes mixed with yellow ochre and fatty substances— that might represent the 'seal tar' mentioned in the Saga of Erik the Red (Brøgger \& Shetelig 1951: 116; Arbman 1993: 31; Egenberg 2003: 63, Ravn 2016: 32). Although tar may also have been used for treating ropes in ship rigging, there seems to have been a preference for making ropes from lime or linden bast fibres for Danish Viking Age boats at least, with no archaeological traces of tar treatment in evidence. Tar was probably not required here, as lime bast ropes become stronger when wet (Ravn 2016: 50). The situation is different for Norway, however, where several examples of tar-treated hemp ropes have been found (Hiorth 1908: 18-23).

Large quantities of tar were probably used for treating sails. Experiments show that woollen sails perform better than other materials, as they provide more elasticity in strong winds. Woollen sails, however, are highly permeable and require a sealing coat, or smörring, to be applied to their front side (Cooke et al. 2002: 207; Larsson 2007: 93). Archaeological sail fragments and historical and ethnological sources show that different mixtures of fat, grease, tar or other resinous substances, as well as ochre, were used (Andersson 1995: 255; Cooke et al. 2002: 205; Ravn 2016: 47). In experiments, tar comprises only a few per cent of the coating mixture, but for the large Viking Age ships, the size of the sails was around $100 \mathrm{~m}^{2}$. The total area of the sails of the Danish-Norwegian Late Viking Age fleet is estimated at approximately one million square metres (Bender Jørgensen 2012: 179; Hvid \& Ravn 2016: 182). This substantial area (also including Swedish ships) suggests that a considerable amount of tar was needed for sail coating.

The coating on boats and sails also required continuous maintenance, which will have driven a constant demand for tar. Tar-production features in contexts that indicate such continuous use have been found at sites associated with boat maintenance. One example, excavated in the late 1980s, is Herrebro in Sweden. At the time of excavation, the link between tar production and funnel-shaped pits had not yet been established. Such a reinterpretation of the Hererbo features, however, seems highly plausible, based on stratigraphic profile drawings. One of the two pits was radiocarbon dated to the ninth or tenth century AD (Figure 5; Lindeblad et al. 1994: 48-49, 57). Other examples are found among Viking remains beside Russian rivers. So far, the oldest tar-production feature discovered here is at the port site of Gnezdovo by the Dnieper River, which yielded two tenth-century funnel-shaped tar pits associated with evidence for the loading, unloading and maintenance of Viking ships (Figure 5; Fetisov \& Muraševa 2008). Another example comes from Vyplozov on the Desna River in the Ukraine, where excavations have revealed ceramic fragments with traces of tar from ditches interpreted as landing spots for Viking Age ships (A.A. Fetisov pers. comm.).

As stated above, several different sources provide evidence for the use of tar within shipping, and the size of the Late Viking Age fleets suggests an extensive and continuous need for the product. The increasing need for tar entails changes in the transportation and (C) Antiquity Publications Ltd, 2018 


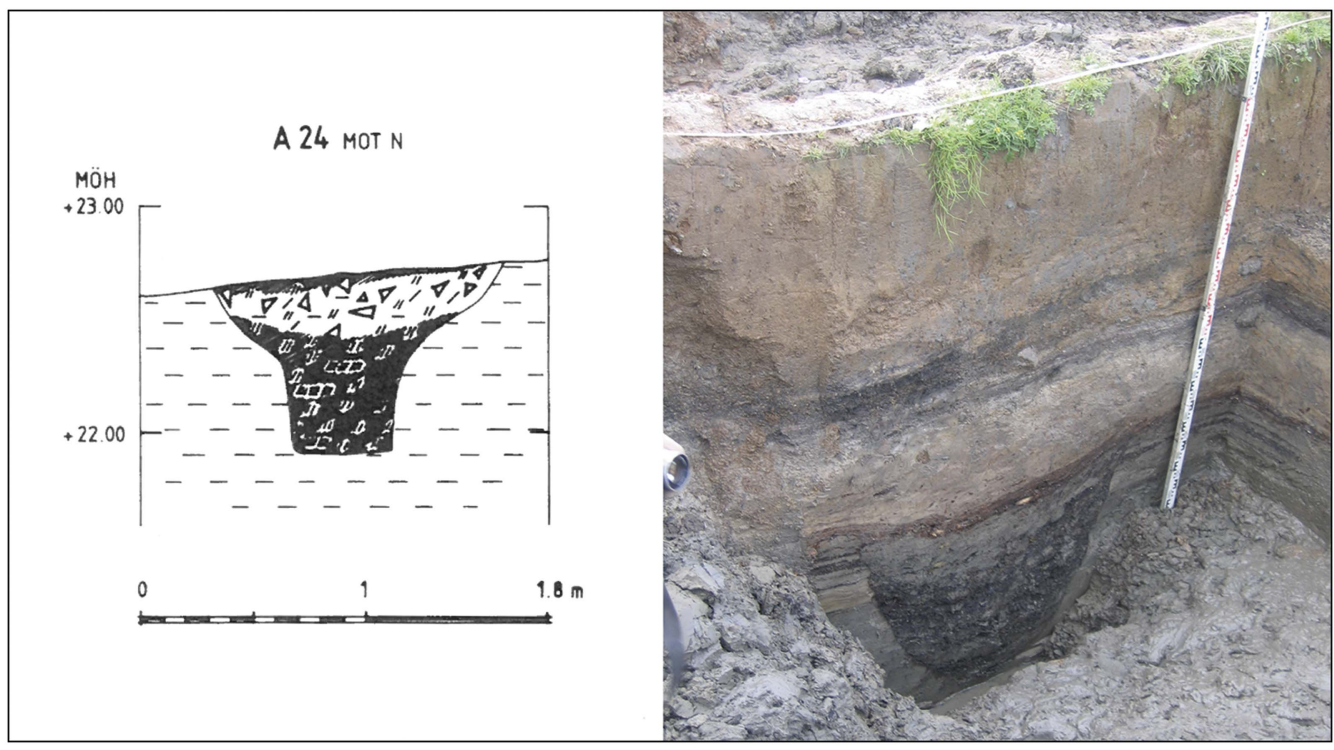

Figure 5. Tar pit excavated in Herrebro (reinterpreted) from Lindeblad et al. (1994) and tenth-century tar pit from the Gnezdovo site, Smolensk region. (Excavations by V.V. Murasheva, State Historical Museum, 2006-2007; photograph by A.A. Fetisov, State Museum of Oriental Art.)

organisation of labour, and makes it more probable that a commodities trade in tar was initiated, connecting the forested outlands with inter-regional trade networks.

\section{Tar as a trade commodity}

The identification of archaeological organic substances as trading commodities is challenging. When tar is discussed from this perspective, one must also consider the natural landscape and the availability of sufficient coniferous wood for tar production. The long-distance transportation of timber is generally considered to have begun in the thirteenth century AD (Ravn 2016: 91), although evidence from several Scandinavian Viking Age trading centres suggests a much earlier trade in refined wood tar. Ceramics from the Swedish emporia of Birka, for example, show traces of tar, which Frostne (2002: 22) interprets as evidence for tar collection, storage or processing. Underwater excavations in the harbour basin have yielded a tar brush and a birch-bark vessel containing tar (Stahre 2012; Lindström 2014).

Ribe in Denmark provides evidence for long-distance tar trading earlier than the Viking Age. A well excavated on the site incorporated a reinforced lining in the form of a barrel, the interior of which preserved thick layers of tar made from either pine, spruce or larch. Dendrochronological analysis shows that this barrel came from Nieder Sachsen (modern Lower Saxony in north-west Germany), and dates to the early eighth century AD. The tar was probably produced around the Harz area (northern Germany), and was transported to Ribe via the River Elbe (Bencard et al. 1990: 59-60, 145). Further evidence for tar use has been found in the harbour basin of the Viking Age town of Hedeby/Haithabu, which yielded over 90 brushes used for the application of $\operatorname{tar}$ (Ravn 2016:31). Kalmring (2010:370-71) reports on finds from Schleswig, where several wooden troughs, made from split logs of pine and

(C) Antiquity Publications Ltd, 2018 
used for the transportation of tar, have been discovered. As local coniferous wood was scarce, it is suggested that the tar was brought from the Duchy of Lauenburg, the southern Baltic coast areas, Sweden or Finland.

\section{Discussion}

Based on the evidence presented above, I suggest that tar production in eastern Sweden developed from a small-scale household activity in the Roman Iron Age to large-scale production that relocated to the forested outlands during the Vendel/Viking Period. This change, I propose, resulted from the increasing demand for tar driven by an evolving maritime culture. This shift in production was also paralleled by similar changes in the refinement of other commodities. The beginning of the Late Iron Age, for example, saw an expansion of activities external to settlements, and colonisation of marginally used areas, such as forests, coastal areas and mountains. There was also a concurrent increase in the exploitation of non-agrarian resources, evidenced by hunting, fishing and iron production (Magnusson 1986: 221-22; Landin \& Rönnby 2002; Lindholm \& Ljungkvist 2015: 18 19). In relation to this wider picture, the following discussion considers the social organisation of tar production and the local and regional circulation of tar products.

Prehistoric tar production could have been organised in many different ways, in a multitude of combinations, possibly under the control of political or economic elites. Tar production could have been conducted by individual, free farmers, or cooperatively by organised groups of farmers. It could also have been a strategy used by other groups of people who found new income from exploiting non-agrarian forest products. Scandinavian Late Iron Age society was also a slave-based economy (Brink 2012: 259, 262). In the Old Norse poem Rigspula, for example, the thralls (serfs or slaves) are said to have performed heavy work, such as building stone fences and digging for peat (Brink 2012: 169-71). According to Swedish medieval laws, male slaves shepherded grazing animals, in addition to undertaking woodland labour and fishing (Nevéus 1974: 68, 87, 113, 139).

The lack of graves or settlement evidence close to the forest tar pits, however, may suggest that tar production was managed from the agrarian-based settlements located in the river valleys (Figure 6). Historical accounts and maps of the forest areas containing tar pits show a correlation between the tar-production sites and historically known shielings (in Swedish, Fäbod or Säterseasonally used occupation areas away from the home farm, and often associated with transhumance and grazing animals, but also other types of activities) (Hennius et al. 2005: 43). We know from both Norway and Iceland that the shielings were part of the Viking Age agricultural system, and were typically situated about $2 \mathrm{~km}$ from the home farm, with some examples up to 15km away (Skrede 2005: 40; Kupiec \& Milek 2015: 108). Sindbæk (2011: 103, 108) proposed that outland shielings were important for surplus production and wealth in Viking Age Denmark. The economic focus was on animal grazing, but it was also combined with a wide range of other resources. The tar-production sites were often placed close to low-lying areas suitable for haymaking and grazing, and could be viewed as integrated within a shieling system, where seasonal tar production was combined with other activities on task-specific sites away from the ordinary settlements. This represents a transition from the Early Iron Age widespread grazing system (Petersson 2006: 262-63) to one of seasonally based camps, which later evolved into the (C) Antiquity Publications Ltd, 2018 


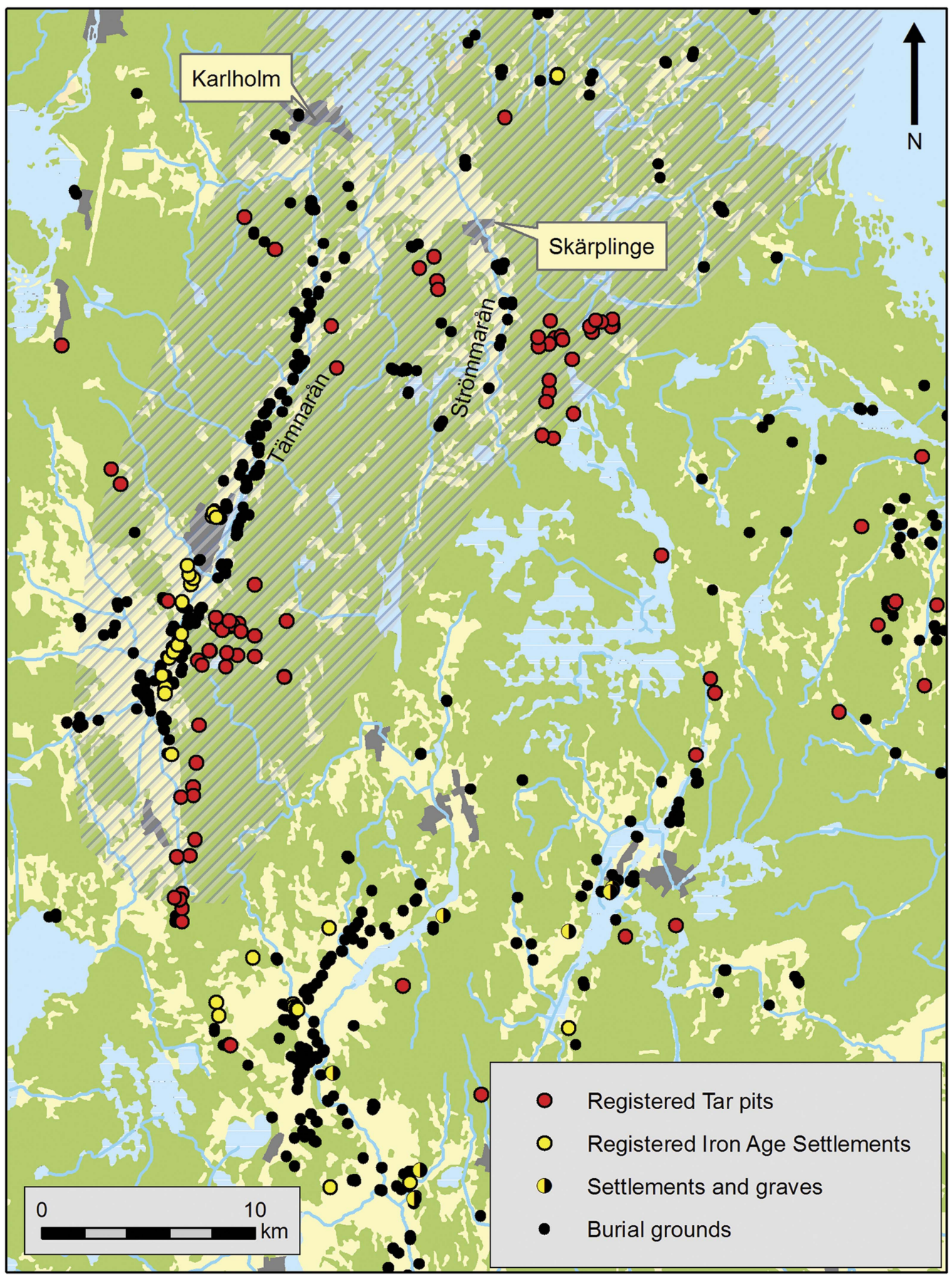

Figure 6. Map showing the northern part of the province of Uppland, where the great majority of tar-production pits are registered. A concentration along waterways is clearly evident. Hatched area corresponds to archaeological region 40a, according to Hyenstrand (1984). 
historically documented shielings. The pattern of outland use, based on a field-and-meadow system, seems to have been established in several places during the Late Iron Age (Karlsson \& Emanuelsson 2002: 124-27; Emanuelsson et al. 2003: 130). This spatial organisation would imply that people were released from agrarian work to spend time in the forest on the production of tar, and perhaps other activities. Such specialisation could also make use of spare farm labour during quieter periods within the agricultural cycle. In historical times, tar production was conducted by farmers, and could easily be integrated with the agricultural calendar (Villstrand 1996: 69-72).

A by-product of tar production is charcoal. The process of manufacturing charcoal is similar to that for tar-burning wood in a low-oxygen environment. The quantity of charcoal found in association with the tar pits, however, is surprisingly low, given the volumes of wood used in tar production. It is possible that the charcoal was used in iron-production, an activity that needed large volumes of fuel, and thus further increased the profit from tar production. Few iron-production sites contemporaneous with the tar-production features, however, have been identified in the area.

The presence of barrels, buckets, brushes and troughs in Viking Age emporia indicates the importation and use of tar. The connection between the tar-production areas in the forests of northern Uppland and the market, however, is unknown. The production area is dominated by the Rivers Tämnarån and Strömmarån, which run northwards to the Baltic Sea (Figure 6). Based on the specific characteristics of its ancient remains, the area has been characterised as its own region (region 40a, Hyenstrand 1984: 189), separate from the southern parts of Sweden. Few archaeological excavations have been conducted in Karlholm and Skärplinge, where the two rivers discharge. The Swedish Archaeological Sites and Monuments database as well as artefacts deposited at the Swedish History Museum (FMIS Västland 102/SHM 23115 resp. FMIS Österlövsta 206:1/SHM 26335; www.fmis. raa.se), however, record evidence of Viking Age wealth and trade at both places, including swords, balance scales and jewellery. In late fourteenth-century historical accounts, Skärplinge is documented as one of many smaller marketplaces along the Baltic coast, trading in grain, fish, meat and butter, and probably also down feather and seal blubber (Broberg 1990: 116-17). Trade was very probably already initiated at these coastal sites in the Viking Age, where tar could be loaded for onward transport within inter-regional trade networks.

\section{Conclusions}

Recent archaeological excavations have cemented the link between previously poorly understood funnel-shaped features and the production of tar. It has also been possible to trace the development from small-scale, settlement-based household tar production to largescale production in the forested outlands, immediately prior to the Viking Age. This development coincides with Scandinavian society's intensified marine focus and the introduction of the sail. This most probably drove the increase in tar production, which was used for protecting wood, impregnating and sealing sails, and as a trade product. Tar production may have been combined with other seasonal activities in a shieling-like system

(C) Antiquity Publications Ltd, 2018 
controlled from the settlements in the agrarian river valleys. The tar was transported by river to smaller marketplaces on the Baltic coast and, from here, onwards to emporia. The forested outlands, therefore, played an integral part in the larger inter-regional networks.

\section{Acknowledgements}

I wish to thank the Berit Wallenberg Foundation (grant BWS2014.0117) for funding this work, together with the 'Viking Phenomenon' project from the Swedish Research Council (grant 2015-00466). I also thank Jonas Svensson-Hennius for sharing the compilation of ${ }^{14} \mathrm{C}$-datings, Calum McDonald for language revision and the two anonymous reviewers for their valuable comments.

\section{References}

Andersson, E. 1995. Woollen material for sails, in O. Olsen, J. Skamby-Madsen \& F. Rieck (ed.) Shipshape. Essays for Ole Crumlin-Pedersen on the occasion of his $60^{\text {th }}$ anniversary, February $24^{\text {th }} 1995$ : 249-70. Roskilde: The Viking Ship Museum.

Andersson, K. 2005. Sjuran-en grav-och kultplats från bronsåldern. Arkeologiska forskningsundersökningar vid Sjurån (Stockholms Länsmuseum. Rapport 2005). Stockholm: Stockholms Länsmuseum.

Arbman, H. 1993 (Facsimile). Der Årby-fund, in C.-O. Cederlund (ed.) The Arby boat (The Museum of National Antiquities Monographs 2): 15-80. Stockholm: Statens historiska museum and Båtdokumentationsgruppen.

Bencard, M., L. Bender Jörgensen \& H. Brinch Madsen. 1990. Ribe excavations 1970-76. Esbjerg: Sydjysk Universitetsforlag.

Bender Jörgensen, L. 2012. The introduction of sails to Scandinavia: raw materials, labour and land, in R. Berge, M.E. Jasinski \& K. Sognnes (ed.) N-TAG TEN-Proceedings of the $10^{\text {th }}$ Nordic TAG conference at Stiklestad, Norway 2009 (British Archaeological Reports International series 2399): 173-81. Oxford: Archaeopress.

Berggren, A. \& A. Hennius. 2004. Sommaränge. Hus, odling och tjärframställning (Upplandsmuseet rapport 2002:02). Uppsala: Avdelningen för arkeologiska undersökningar, Upplandsmuseet.

Bergström, H. 1941. Handbok för kolare. På Uppdrag av jernkontoret. Tredje upplagan. Stockholm: Esselte.

BJöRCK, N. 2008. Väg 709—ett snitt genom Vendels förhistoria. Riksantikvarieämbetet. Uppsala: Avdelningen för arkeologiska undersökningar UV-Mitt.
BRINK, S. 2012. Vikingarnas slavar-Den nordiska träldomen under yngre järnålder och äldsta medeltid. Stockholm: Bokförlaget Atlantis AB.

Broberg, A. 1990. Bönder och sambälle $i$ statsbildningstid. En bebyggelsearkeologisk studie av agrarsambället i Norra Roden 700-1350

(Rapporter från Barknåre-projektet III. Upplands fornminnesförenings tidskrift 52). Uppsala: Stockholm University.

Brøgger, A.W. \& H. Shetelig. 1951. The Viking ships. Their ancestry and evolution. Oslo: Dreyers.

Bronk Ramsey, C. 2009. Bayesian analysis of radiocarbon dates. Radiocarbon 51: 337-60. https://doi.org/10.1017/S0033822200033865.

Bruce-Mitford, R. 1975. The Sutton Hoo shipburial. Volume 1, excavations, background, the ship, dating and inventory. London: Publications for the Trustees of the British Museum.

Cooke, B., C. Christiansen \& L. Hammarlund. 2002. Viking woollen square-sails and fabric cover factor. International Journal of Nautical Archaeology 31: 202-10.

https://doi.org/10.1111/j.1095-9270.2002. tb01414.x.

Egenberg, I. M. 2003. Tarring maintenance of Norwegian medieval stave churches. Characterisation of pine tar during kilnproduction, experimental coating and weathering. Göteborg: Acta Universitatis Gothoburgensis

Emanuelsson, M., A. Johansson, S. Nilsson, S. Pettersson \& E. Svensson. 2003. Settlement, shieling and landscape. The local history of a forest hamlet (Lund Studies in Medieval Archaeology 32). Lund: Lund University.

Fetisov, A.A. \& V.V. Muraševa. 2008. Smolokurennoe proizvodstvo $v$ Gnezdove Starodavnij Iskorosten' i starodavni grady. Zbirka naukovych prac (Tom 2. Korosten). Moscow: State Museum of Oriental Art. 
Fredman, P.-O. 2009. Skog \& Historia i Uppsala län (Skogsstyrelsen Rapport 2: 2009). Jönköping: Skogsstyrelsens.

Frostne, J. 2002. Krukskärvorna på Birka berättarorganisk analys av krukskärvor frän främst Birkas Garnison, med GC-MS och FTIR (C/D Uppsats i Laborativ Arkeologi 01/02). Stockholm: Arkeologiska Forsknings Laboratoriet, Stockholms Universitet.

Hennius, A. 2007. En mörk tid i Uppländsk ekonomi, in E. Hjärthner-Holdar, H. Ranheden \& A. Seiler (ed.) Land och sambälle i förändring, Uppländska bygder $i$ ett långtidsperspektiv (Volym 4, Arkeologi E4 studier): 597-611. Uppsala: Riksantikvarieämbetet UV Gal, Societas Archaeologica Upsaliensis, Upplandsmuseet. - 2016. Arkeologiska lämningar i skogsmark: Arkeologisk forskningsundersökning Dannemora 102:1, Österlöusta 970 \& 974 Dannemora och Österlöusta Socknar, Tierps Kommun, Uppsala Län, Uppland. Uppsala: Institutionen för Arkeologi och Antik Historia, Uppsala Universitet.

Hennius, A., J. Svensson, A. Ölund \& H. GöTHBERG. 2005. Kol och tjära-Arkeologi i norra Upplands skogsmarker (Rapport 2005:02). Uppsala: Avdelningen för arkeologiska undersökningar, Upplandsmuseet.

Heron, C., R.P. Evershed, B. Chapman \& A.M. Pollard. 1991. Glue, disinfectant and 'chewing gum' in prehistory, in P. Budd, B. Chapman, C. Jackson, R. Janaway \& B. Ottaway (ed.) Archaeological sciences 1989. Proceedings of a conference on the application of scientific techniques to archaeology, Bradford, September 1989 (Oxbow Monograph 9). Oxford: Oxbow.

Hiorth, J. 1908. Undersøgelser af forhistorisk uld og tøjrester fundne Norske gravhauger, in Stavanger Museums aarshefte for 1908. Stavanger: Stavanger Museum.

Hjulström, B., S. Isaksson \& A. Hennius. 2006. Organic geochemical evidence for pine tar production in middle eastern Sweden during the Roman Iron Age. Journal of Archaeological Science 33: 283-94. https://doi.org/10.1016/j.jas.2005.06.017.

Hvid, C. \& M. RAvn. 2016. Barkning og smøring af sejl—praktiske erfaringer samt refleksion over vikingetidens imprægnering af sejldug, in H. Lyngstrøm \& M. Ravn (ed.) Vikingetidens Sejl. Festskrift tillegnet Erik Andersson (Arkæologiske skrifter 14): 173-87. København: Saxo-institutet, Københavns Universitet.
Hyenstrand, A. 1984. Fasta fornlämningar och arkeologiska regioner (RAÄ och Statens historiska museer, Rapport 1984:7). Stockholm: Riksantikvarieämbetet.

Kalmring, S. 2010. Der Hafen von Haithabu. Die Ausgrabungen in Haithabu, Vierzehnter Band. Neumünster: Wachholtz.

Karlsson, H. \& M. Emanuelsson. 2002. Fäbodväsendets långa historia. En diskussion utifrån vegetationsförändringar vid Öjningsvallen under 1500 år, in E. Johansson (ed.) Periferins landskap. Historiska spår och nutida blickfält i svensk glesbygd: 123-40. Lund: Nordic Academic.

Konsa, M. 2013. Two Vendel-era ship burials at Salme on the Island of Saaremaa, in M. Loit, K. Matteus \& A. Randla (ed.) Estonian cultural heritage-preservation and conservation: 152-56. Tallinn: National heritage board, Tallinn culture and heritage department, Department of Cultural heritage and conservation at the Estonian academy of arts.

Kupiec, P. \& K. Milek. 2015. Roles and perceptions of shielings and the mediation of gender identities in Viking and medieval Iceland, in M. Hem Eriksen, U. Pedersen, B. Rundberget, I. Axelsen \& H. Lund Berg (ed.) Viking worlds. Things, spaces and movement: 102-23. Oxford: Oxbow.

Kurzweil, A. \& D. Todtenhaupt. 1998. Teer und Holz. Unpublished information folder, Museumdorfes Düppel, Berlin.

Landin, M. \& J. Rönnby. 2002. Tomtningar i utskärgården frän yngre järnåldern. Arkeologiska undersökningar på Landsort, Torö socken, Södermanland (Research reports 6:2002). Huddinge: Södertörns Högskola.

LARsson, G. 2007. Ship and society: maritime ideology in the Late Iron Age Sweden (Aun 37). Uppsala: Department of Archaeology and Ancient History, Uppsala University.

Lindeblad, K., R. Hedvall \& A.-L. Nielsen. 1994. Herrebro: Hällristningar och marknad: arkeologiska undersökningar av fornlämning $51 i$ Borgs socken, Östergötland (Uv-Rapporter 1993: 9). Stockholm: Riksantikvarieämbetet och statens historiska museer.

LINDSTRÖM, J. 2014. En hink med vikingatida tjära! Available at: http://marinarkeobloggen.sjohistoriska.se/post/ En-hink-med-vikingatida-tjara (accessed 12 September 2018). 
Lindholm, K. \& J. Ljungkvist. 2015. The bear in the grave: exploitation of top predator and herbivore resources in first millennium Sweden - first trends from a long-term research project. European Journal of Archaeology 19: 3-27. https://doi.org/10.1179/1461957115Y. 0000000010.

Magnusson, G. 1986. Lågteknisk järnhantering i Jämtlands län (Jernkontorets Bergshistoriska Skriftserie N:r 22). Stockholm: Stockholm University.

Nevéus, C. 1974. Trälarna i landskapslagarnas sambälle i Danmark och Sverige (Studia historica Upsaliensis 58). Uppsala: Acta Universitatis Upsaliensis.

Peets, J., R. Allmäe, L. Maldre, R. SaAge, T. TомеK \& L. Lõugas. 2012. Research results of the Salme ship burials in 2011-2012. Archaeological fieldwork of Estonia 2012: 1-18. Talinn: Muinsuskaitseamet.

Persson, T. 1994. Jag väntar, vid min mila. En studie av förhistorisk träkols- och tjärframställning $i$ Skandinavien (C-Uppsats i arkeologi). Lund: Arkeologiska Institutionen, Lunds Universitet.

Petersson, M. 2006. Djurhållning och betesdrift: djur, människor och landskap i västra Östergötland under yngre bronsålder och äldre järnålder. Uppsala: Institutionen för arkeologi och antik historia, Uppsala universitet.

Price, T.D., J. Peets, R. Allmäe, L. Maldre \& E. Oras. 2016. Isotopic provenancing of the Salme ship burials in pre-Viking Age Estonia. Antiquity 90: 1022-37. https://doi.org/10.15184/aqy.2016.106.

RAvN, M. 2016. Viking-Age war fleets: shipbuilding, resource management and maritime warfare in $11^{\text {th }}$-century Denmark. Roskilde: The Viking Ship Museum.

Reimer, P.J., M.G.L. Baillie, E. Bard, A. Bayliss, J.W. Beck, C.J.H. Bertrand, P.G. Blackwell, C.E. Buck, G.S. Burr, K.B. Cutler, P.E. Damon, R.L. Edwards, R.G. Fairbanks, M. Friedrich, T.P. Guilderson, A.G. Hogg, K.A. Hughen, B. Kromer, G. McCormac, S. Manning, C. Bronk Ramsey, R.W. Reimer, S. Remmele, J.R. Southon, M. Stuiver, S. Talamo, F.W. TAYlor, J. van DeR Plicht \& C.E. WeyhenMeyer. 2004. IntCal04 terrestrial radiocarbon age calibration, $0-26$ cal kyr BP. Radiocarbon 46: 1029-58.
SinDвÆK, S.M. 2011. Social power and outland use in Viking Age settlement, in B. Poulsen \& S.M. Sindbæk (ed.) Settlement and lordship in Viking and early medieval Scandinavia: 97-118. Turnhout: Brepols. https://doi.org/10.1484/M.TMC-EB.4.1006.

Skrede, M.A. 2005. Shielings and landscape in western Norway-research traditions and recent trends, in I. Holm, S. Innselset \& I. Øye (ed.) Utmark - the outfield as industry and ideology in the Iron Age and the Middle Ages (Archaeological Series International 1): 31-41. UBAS. Bergen: University of Bergen.

STAHRE, S. 2012. Med marinarkeologerna på Birka. Available at: https://birkaproject.wordpress.com/2012/08/ 30/med-marinarkeologerna-pa-birka/ (accessed 12 September 2018).

Svensson, J. 2007. Upplands tidiga tjärbränning, ett uråldrigt hantverk, in E. Hjärthner-Holdar, H. Ranheden \& A. Seiler (ed.) Land och sambälle i förändring, Uppländska bygder i ett langtidsperspektiv. Volym 4: 613-41. Uppsala: Riksantikvarieämbetet UV Gal, Societas Archaeologica Upsaliensis, Upplandsmuseet.

Svensson-Hennius, J. 2017. Unpublished compilation of ${ }^{14} \mathrm{C}$-datings from tar pits.

Swedish Archaeological Sites and Monuments database, FMIS. Available at: http://www.fmis.raa.se/cocoon/fornsok/search. html (accessed 14 September 2018).

Villstrand, N.E. 1996. En räddande eld. Tjärbränning inom det svenska riket 1500 1800, in B. Liljewall (ed.) Tjära, barkbröd och vildhonung (Skrifter om skogs- och lantbrukshistoria 9): 62-77. Stockholm: Nordiska Museet.

Received: 13 September 2017; Revised: 5 January 2018; Accepted: 5 February 2018 